\title{
The activities of endothelial elastase and cathepsin $G$ in rats at oxidative stress caused by heavy metals salts
}

\author{
Nickolaj F. Starodub ${ }^{1}$, Ljubov M. Samokhina ${ }^{2}$ \\ ${ }^{1}$ National University of Life and Environmental Sciences of Ukraine, Kiev, Ukraine \\ ${ }^{2}$ Institute of Therapy of the L. T. Malaya of AMS of Ukraine, Kharkov, Ukraine \\ Email: nikstarodub@yahoo.com, lub.samokhina@yandex.ua
}

Received 17 January 2013; revised 10 March 2013; accepted 13 April 2013

Copyright (C) 2013 Nickolaj F. Starodub, Ljubov M. Samokhina. This is an open access article distributed under the Creative Commons Attribution License, which permits unrestricted use, distribution, and reproduction in any medium, provided the original work is properly cited.

\begin{abstract}
$\mathrm{CoCl}_{2}$ introduction increased cathepsin $\mathrm{G}$ activity in the heart and liver as well as endothelial elastase (EEI) in kidney that indicated the development of destructive processes. $\mathrm{CoCl}_{2}$ introduction decreased $\mathrm{EEI}$ and cathepsin $\mathrm{G}$ activities in blood serum and cathepsin $\mathrm{G}$ in lungs. $\mathrm{HgCl}_{2}$ injection decreased $\mathrm{EEl}$ in blood serum, heart, liver, kidney and cathepsin $G$ in blood serum. These decreasing of proteinases activities may be caused by cytotoxic effects of heavy metals and/or the inclusion of these proteases in the destructive processes and absence of their synthesis and/or release.
\end{abstract}

Keywords: Endothelial Elastase; Cathepsin G; Cobalt Chloride; Mercury Chloride; Rats

\section{INTRODUCTION}

Heavy metal ions exhibit cytotoxicity and significantly affect on the health of the human [1,2]. They may increase the release of reactive oxygen species (ROS) that results in cell damage due to oxidative stress [3]. $\mathrm{CoCl}_{2}$ is widely used to simulate oxidative stress [4,5]. Its prooxidant effect is determined by the ability to directly interact with the free radicals of oxygen and hydrogen peroxide and as result of activating the enzyme systems of ROS release and decreasing level of antioxidants [6]. It is known, that the effect of $\mathrm{CoCl}_{2}$ is the result of activation of the processes of lipid peroxidation, reducing concentration of extracellular superoxide dismutase and compensatory increasing catalase activity [5,7]. $\mathrm{CoCl}_{2}$ also to protect cells through removing adiponectin in adipocytes via an intracellular mechanism independent of tumour necrosis factor $\alpha$ which can be as result of metabolic disorders [7].

It should be also noted that at physiological conditions in an organism cobalt, iron, copper, chromium and vanadium are exposed to the redox cyclic reactions while other metals such as mercury, cadmium, nickel and arsenic enhance oxidative stress indirectly by increasing the level of oxidized glutathione and binding with sulfhydryl groups of proteins [8].

Special interest is now being given to influence of mercury $[9,10]$. There is information on low doses of mercury effect on endothelial modulation of coronary blood circulation [10]. The basic mechanisms of increased cardiovascular risk in response to mercury is still not fully understood $[9,10]$.

In endothelial function realization an important role is belonging to the endothelial thiol elastase (EEl). Such activation may be associated with the development of morphofunctional disorders of the vascular structures and the nature of the metabolic processes. EEl can destroy extracellular matrix components such as elastin and collagen which are fundamental structural elements of the arterial wall and may be involved in vascular function, arterial aging, and atherosclerosis [11]. In the literature, contradictory results have been reported about the associations of serum elastase parameters with atherosclerosis. The results of experimental animal studies and human studies, conducted in Europe, Canada, and the United States, were inconsistent but tended to support the hypothesis of deleterious atherogenic effects of elastase. Paradoxically, most Japanese studies have shown opposite results and have suggested that elastase may prevent atherosclerosis and arterial wall dysfunction. The associations of arterial wall dysfunction with serum EEl activity was unexpected and remains difficult to explain.

Special interest may be the study of cathepsin G (EC 3.4.21.20), which is a serine protease of neutrophil cytoplasmic azurophilic granules acting in combination with ROS [12]. Upon neutrophil activation, granular cathepsin 
$\mathrm{G}$ are secreted extracellularly, these protease are released from neutrophil cell surfaces by high concentrations of salt. Cathepsin $\mathrm{G}$ is degradated the myosin, elastin, proteoglycans, laminin, collagen, immunoglobulins $\mathrm{G}$ and $\mathrm{M}$ [13].

Cathepsin $\mathrm{G}$ functions are allocated with platelet activation, proteolysis of blood clotting factors, chemotaxis and etc. Cathepsin $G$ is one of several enzymes transforming angiotensin I into angiotensin II and is also capable of cleaving angiotensin II directly from angiotensinogen [14]. Cathepsin G can activate the TGF-beta pathway, resulting in myocyte necrosis, hypertrophy, and increased fibrosis, it may play a role in the progression to heart failure by activating angiotensin II, leading to detrimental effects on the heart [15]. Cathepsin G prefers the bulky hydrophobic amino acid Leu and accepts the bulky aromatic amino acids Phe and Tyr [16]. Cathepsin $\mathrm{G}$ shows a strong preference for the charged amino acid Lys at $\mathrm{P}(1)$ in tropoelastin, whereas Lys was not identified at $P(1)$ in cathepsin $G$ digests of elastin due to extensive cross-linking at Lys residues in mature elastin.

Relationship of changes in the activity of cathepsin G and EEl in the development of organs dysfunction remains to be unclear.

The main purpose of this work is the determination of the activity of the cathepsin G and the EEl at the oxidative stress caused by the introduction of cobalt and mercury salts.

\section{MATERIALS AND METHODS}

\subsection{Experimental Animals and Experimental Design}

Male Wistar rats 2 - 3 months old were injected intraperitoneally by the cobalt chloride $\left(\mathrm{CoCl}_{2} \cdot 6 \mathrm{H}_{2} \mathrm{O}\right)$ in a dose of $3 \mathrm{mg} / 100 \mathrm{~g}$ body weight $(\mathrm{n}=6)$ or chloride of mercury $\left(\mathrm{HgCl}_{2}\right)$ at the rate of $0.7 \mathrm{mg}$ per $100 \mathrm{~g}$ body weight $(\mathrm{n}=6)$ in $0.9 \%$ solution of $\mathrm{NaCl}[17,18]$. Control animals $(\mathrm{n}=6)$ were injected the saline in the appropriate volume. Rats were decapitated at $2 \mathrm{~h}$ after injection.

The study was conducted in accordance with the "General principles of work with animal, approved by the III National Congress on Bioethics" (Kiev, 2007) and consistent with the provisions of the "European Convention for the Protection of Vertebrate Animals that are used for experimental and other scientific purposes" (Strasbourg, 1985) Animals were kept in a vivarium on a standard diet.

\subsection{Preparation of Tissue Homogenates}

A blood was collected into centrifuge tubes to obtain serum. The liver was perfused with cold saline solution. The tissues of lung, heart, liver and kidney $(300 \mathrm{mg}$ ) were homogenized in $3 \mathrm{ml}$ of Na-phosphate buffer $\mathrm{pH}$
7.4 at $4^{\circ} \mathrm{C}-6^{\circ} \mathrm{C}$. Blood and the resulting homogenates were centrifuged for $10 \mathrm{~min}$ at $5000 \mathrm{~g}$ in a centrifuge RS6 at $4^{\circ} \mathrm{C}$. Samples were stored at $-20^{\circ} \mathrm{C}$ until analysis.

\subsection{Enzyme Assays}

The EEl and cathepsin G activities were determined in non-nuclear fractions of the homogenates of the above mentioned tissues using highly sensitive enzymatic methods $[19,20]$. Their principle is based on the use for the proteolytic reactions of the complexes of the marked enzyme (horseradish peroxidase) and substrates of protein nature which were immobilized on polystyrene. The level of residual activity of the enzyme marker was set on the magnitude of the optical density which was measured at $490 \mathrm{~nm}$.

Determination of the EEl activity is based on the classification of enzymes of the NC-IUBMB on the mechanism of their catalysis, allowing to isolate thiol (cysteine) proteases (EC 3.4.22) [21,22]. These proteases are differing in the sensitivity to inhibitors $[22,23]$. The substrate in the estimation of the EEl was N-Succinyl-AlaAla-Val. Elastase with activity from 0.0005 to $0.5 \mathrm{U} / \mathrm{mg}$ protein was taken as control samples [20]. Prior to the proteolytic reaction the activity of the serine and metalloproteinases were inhibited by addition to the investigated samples of inhibitor solution in ratio of 1:1. This solution contained $0.02 \%$ fenilsulfonilflyuoride and $6 \%$ ethylenediaminetetraacetate.

The substrate in case of the assessing of the cathepsin $\mathrm{G}$ activity was a fragment of angiotensin II $5-8$, that conjugated metaperyodate method with horseradish peroxidase and immobilized on polystyrene by drying a solution of $0.5 \mathrm{M}$ ammonium bicarbonate. Unbound molecules are washed with distilled water containing $0.5 \%$ non-ionic detergent Tween 20. Control was presented by a cathepsin G $(0.05-1.00) \mathrm{mg} / \mathrm{ml}$ [19]. In order to increase of the analysis specificity the trypsin-like enzymes, which can cleave the globular proteins such as a marker enzyme, were inhibited in the reaction with aprotinin. For this separately on titration plate researched samples are prepared $(n=40)$ and control samples are brought in titration plate $(\mathrm{n}=8)$. The aprotinin $20 \mu \mathrm{g} / \mathrm{ml}$ were added to the test samples 1:1 by volume, incubated during $5 \mathrm{~min}$ at $37^{\circ} \mathrm{C}$. Then the proteolytic reaction of cleavage of immobilized enzyme-substrate complex was performed. For this the reaction mixture was introduced into the wells and incubated for $15 \mathrm{~min}$ at $37^{\circ} \mathrm{C}$. The reaction products were removed money and the level of residual activity of the enzyme marker was set as before.

The EEl and the cathepsin G activities were expressed as $\mathrm{U} / \mathrm{mg}$ of proteinx $10^{-3}$ and $\mathrm{mg} / \mathrm{lxh}$, respectivelly. The protein concentration was determined by Bradford assay [24]. 


\subsection{Reagents and Equipment}

During the investigation it was used polystyrene plates from "Linbro" (USA), a fragment of angiotensin II 5 - 8, horseradish peroxidase, elastase, cathepsin G, N-Succinyl-Ala-Ala-Val, fenilsulfonilflyuoride, aprotinin from "ICN" (USA), microspectrophotometer from "Flow" (UK) and other reagents were domestic manufacture.

\subsection{Statistical Analysis}

Statistical processing of the obtained results was performed by the method of Student-Fisher using the Excel software. The Student criterion t estimation was used as a traditional method of testing the homogeneity of the data in each group and to compare groups. The arithmetic mean of each sample and then the dispersion and the Student criterion $t$ were expected. On this basis the decision for a given level of significance and the number of degrees of freedom $(m+n-2)$ of the t-distribution tables was accepted. If $|t|>t$ critical, the homogeneity hypothesis (no difference) is rejected, if $|\mathrm{t}|<\mathrm{t}$ critical, less than that corresponds to the confidence level of 0.05 , then accepted. Student-Fisher method is based on an assessment of the differences of means for the two groups and the differences between the two dispersions simultaneously.

\section{RESULTS}

$\mathrm{CoCl}_{2}$ and $\mathrm{HgCl}_{2}$ injections in organism leads to decrease of activity of both studied parameters in comparison with control level in blood serum (Table I). There is necessary to mention that changes in the serum of the studied parameters are most pronounced compared with those in the tissues and to a greater extent by the introduction of $\mathrm{CoCl}_{2}$.

It is revealed that $\mathrm{CoCl}_{2}$ injection in organism caused in cathepsin $\mathrm{G}$ activity decreases in lungs in comparison with control level too. At $\mathrm{HgCl}_{2}$ injection in organism EEl activity in all studied samples except of lung tissue and cathepsin $\mathrm{G}$ in blood serum decreased in comparison with control level. Decreasing activities of the studied parameters may be due to their use in destructive processes and absence of synthesis and/or release.

As a result of $\mathrm{CoCl}_{2}$ injection was an increase in the activities of the studied parameters, namely the increase in EEl activity in the kidneys and cathepsin G activity in heart and liver in comparison with control level, which indicates the development and progression of destructive processes.

\section{DISCUSSION}

It is known too, that $\mathrm{CoCl}_{2}$ has toxic action on membranes. It leads to inhibition of the $\mathrm{Na}^{+}, \mathrm{K}^{+}$-ATPase activity, the inhibition of the functional state of kidney, glomerular filtration rate, increasing level of tubular reabsorption of water, and reducing volume of spontaneous urine output [5]. At the same time the electrolyte secretory renal function is violated and the sodium excretion is reduced. It can be assumed that these changes may be due to a violation of the structural integrity of vessel walls because of destructive processes going on EEl participation. These data on kidney are combined with the results of another study which reported that heavy metals can cause renal effects [25].

It is known too, that $\mathrm{CoCl}_{2}$ serves as hypoxia-dependent factor [7,26,27], and endothelial cells respond to hypoxia by decreasing the degradation of hypoxia-inducible factor $1 \alpha$. The accumulation of last leads to increase transcription of numerous proteins involved in cell growth and survival [28], that may cause the increase of EEl activity, synthesized by endothelial cells.

Activation of cathepsin $\mathrm{G}$ in the liver by the introduction of $\mathrm{CoCl}_{2}$ indicates on a functional loading the given organ connected with the processes of detoxification [29]. In addition to, it may indicate an increase of neutrophils release of this enzyme that also is an indicator of oxidative stress [30]. This is consistent with the postulates of the theory of free radical oxidation [1,31]. It should also

Table 1. The endothelial elastase and cathepsin $\mathrm{G}$ activities in rats at oxidative stress caused by heavy metal ions.

\begin{tabular}{|c|c|c|c|c|c|c|}
\hline \multirow[b]{2}{*}{ Biological materials } & \multicolumn{2}{|c|}{ Cobalt chloride } & \multicolumn{2}{|c|}{ Mercury chloride } & \multicolumn{2}{|c|}{ Control } \\
\hline & $\begin{array}{c}\text { Endothelial elastase } \\
\text { activity, } \mathrm{U} / \mathrm{mg} \\
\text { protein } \times 10^{-3}\end{array}$ & $\begin{array}{l}\text { Cathepsin } \mathrm{G} \\
\text { activity, } \mu \mathrm{g} / \mathrm{lh}\end{array}$ & $\begin{array}{c}\text { Endothelial elastase } \\
\text { activity, } \mathrm{U} / \mathrm{mg} \\
\text { protein } \times 10^{-3}\end{array}$ & $\begin{array}{c}\text { Cathepsin G activity, } \\
\mu \mathrm{g} / \mathrm{lh}\end{array}$ & $\begin{array}{c}\text { Endothelial elastase } \\
\text { activity, } \mathrm{U} / \mathrm{mg} \\
\text { protein } \times 10^{-3}\end{array}$ & $\begin{array}{l}\text { Cathepsin } \mathrm{G} \\
\text { activity, } \mu \mathrm{g} / \mathrm{lh}\end{array}$ \\
\hline Blood serum & $0.039 \pm 0.008^{*}$ & $0.092 \pm 0.030^{*}$ & $0.091 \pm 0.027^{*}$ & $0.122 \pm 0.040^{*}$ & $0.821 \pm 0.273$ & $3.92 \pm 1.30$ \\
\hline Lung & $0.788 \pm 0.185$ & $0.158 \pm 0.014^{*}$ & $0.671 \pm 0.167$ & $0.273 \pm 0.085$ & $0.755 \pm 0.251$ & $0.316 \pm 0.069$ \\
\hline Heart & $0.775 \pm 0.332$ & $0.724 \pm 0.164^{*}$ & $0.088 \pm 0.033^{*}$ & $0.179 \pm 0.057$ & $0.287 \pm 0.033$ & $0.273 \pm 0.071$ \\
\hline Liver & $0.554 \pm 0.208$ & $0.545 \pm 0.139^{* *}$ & $0.013 \pm 0.002^{*}$ & $0.115 \pm 0.038$ & $0.416 \pm 0.138$ & $0.153 \pm 0.026$ \\
\hline Kidneys & $1.411 \pm 0.520^{*}$ & $0.133 \pm 0.030$ & $0.066 \pm 0.029^{*}$ & $1.29 \pm 0.60$ & $0.438 \pm 0.178$ & $0.083 \pm 0.014$ \\
\hline
\end{tabular}

${ }^{*} \mathrm{p}<0.05,{ }^{* *} \mathrm{p}<0.01$. 
be noted that $\mathrm{CoCl}_{2}$ at the dose of $15 \mathrm{mg} / \mathrm{kg}$, i.e., higher than used by us, resulting in damage the integrity of the cells, causes the development of cytolysis and necrosis of hepatocytes and ultimately the development of inflammatory processes in the liver [29].

Under the influence of $\mathrm{CoCl}_{2}$ the weight ratio of right ventricle to the total mass of the ventricles is increased and it is observed right ventricular hypertrophy and pulmonary hypertension [32]. At this point of view it may see the correlation of values of this ratio with the level of malondialdehyde (a marker of oxidative damage) in heart tissue. Because of development of oxidative stress in the heart, as in the liver, it may be a release of cathepsin $G$ by neutrophils [30], which is able to form vasoconstrictor peptide angiotensin II from angiotensin I and/or angiotensinogen $[13,14]$. $\mathrm{CoCl}_{2}$ inhibits the reninangiotensin system by reducing the expression of angiotensin I in vascular smooth muscle cells [33]. Thus, we can assume the possibility of formation of angiotensin II from angiotensinogen with cathepsin $G$ participation at the $\mathrm{CoCl}_{2}$ action which contributes to the development of hypertensive changes. Overexpression of cathepsin $\mathrm{G}$ also may lead to decreased number of differentiated smooth muscle cells, to the lower amount of angiotensin 1 receptor in atheroma [34]. Cathepsin G activation in heart can result in myocyte necrosis and increased fibrosis [15]. The latter may be due to cathepsin $\mathrm{G}$ participation in the angiotensin II formation, but not digestion of elastin.

Significant reduction of both the studied parameters in serum at the influencing factors may be due to the rapid penetration of heavy metals ions in tissues [35]. Since the sites of penetration and location of metal particles are often distant from each other the distribution of them through a blood must take place. Endothelial cells located on the internal surface of blood vessels must have the direct contact with the above particles which can lead to a concentration dependent cytotoxicity. It should also be noted that low values of serum elastase activity are strongly and independently associated with increased carotid plaque occurrence and subsequent development of atherosclerosis [11]. This contributes to the development of hypertensive changes, in addition, a more pronounced effect can be expected as a result of $\mathrm{CoCl}_{2}$.

Tissue-specific effects in the lungs may be due to hypoxia-dependent effects of $\mathrm{CoCl}_{2}$ and that these effects may be related to running out of cathepsin $\mathrm{G}$ in the destructive processes. Cobalt is a transition metal ion that can replace iron in oxygen-sensitive protein and mimic hypoxia which contributes to the development of lung disease [36]. It should be noted that $\mathrm{CoCl}_{2}$ induces hypoxia in a sublethal concentration $(100 \mathrm{mM})$. The absence of changes in the studied parameters in the lungs when $\mathrm{HgCl}_{2}$ injected is probably due to the relatively low concentration of the toxicant. It is known that the introduction of $0.68,1.2,2.4 \mathrm{mg} / \mathrm{kg}$ of $\mathrm{HgCl}_{2}$ did not alter the basal cardiorespiratory parameters $[9,10]$. The acute toxic is inducing by a dose of $120 \mu \mathrm{g} / \mathrm{kg}$ which leads to the stop of breathing and death [9].

It is known that the introduction of $60 \mu \mathrm{g} / \mathrm{kg} \mathrm{HgCl}$ causes a significant increase of systolic and diastolic blood pressure which is associated with activation of the sympathetic nervous system. Since we have used a dose of $70 \mu \mathrm{g} / \mathrm{kg}$, we can assume the activation of vasoconstriction although the participation of cathepsin $G$ in this process is not significant character as its changes in heart not valid. The change of the EEl activity can directly effects on the formation of connective tissue proteins, particularly elastin [37]. The decreasing the EEl activity as a result of $\mathrm{HgCl}_{2}$ may be associated with an increased content of elastin, which in turn may lead to the development of myocardial hypertrophy. So our results correlate with those of Japanese studies showing that elastase may prevent atherosclerosis and arterial wall dysfunction.

High total mercury concentrations in the tissues lead to a significant depletion of the liver [38]. The mechanism of oxidative damage associated with increased of lipid peroxidation, thiobarbituric acid reactive substances and the loss of protein-bound thiols. Mercury can bind to sulfhydryl groups of proteins, which leads to a decrease in thiol EEl activity [8]. This may be due to the distortion of metal-responsive transcription factor-1 (MTF-1). MTF-1, also metal regulatory transcription factor-1, is a pluripotent transcriptional regulator involved in cellular adaptation to various stress conditions, primarily expo- sure to heavy metals but also to hypoxia or oxidative stress [39]. MTF-1 is the main activator of metallothionein genes, which encode small cysteine-rich proteins that can scavenge toxic heavy metals and free radicals.

The indicated reduction of EEl activity in the kidneys also may be due to the high total concentration of mercury in their tissues. Toxicity $\left(\mathrm{Hg}^{2+}\right)$ is associated with the disorder of renal function $[25,40]$. It is due to production of the ROS and oxidative stress [40].

It should be noted that a conducted earlier study revealed increased activity of alpha- 1 proteinase inhibitor in the tissues of the heart and kidneys under the influence of the introduction of cobalt chloride in rats [41]. We can assume the possibility of participation of alpha1 proteinase inhibitor in the control of EEl activity in the kidney and cathepsin $\mathrm{G}$ in the heart.

The increase of the activity of another protease inhibitor, namely, alpha-2 macroglobulin in the tissues of the lungs, liver and kidneys, previously noted in the study of the influence of the introduction of mercury chloride in rats [42]. Increased activity of alpha-2 ma- 
croglobulin can reduce the EEl activity.

\section{CONCLUSIONS}

Thereby the injection of $\mathrm{CoCl}_{2}$ in animals leads to increasing cathepsin $\mathrm{G}$ activity in the heart and liver as well as the EEl in kidney. These changes may indicate on the development and progression of destructive processes. The cathepsin $\mathrm{G}$ activation in the liver shows its functional loading in the detoxification processes and increase of neutrophils release of this enzyme as a result of oxidative stress; the latter characterizes a change of heart which in turn may lead to increased formation of angiotensin I from angiotensinogen. The EEl activation in the kidneys may be associated with hypoxia-dependent effects of the toxicant. Decreasing the EEl and cathepsin $\mathrm{G}$ activities in blood serum as a result of both $\mathrm{CoCl}_{2}$ and $\mathrm{HgCl}_{2}$, and cathepsin $\mathrm{G}$ in the lung at the $\mathrm{CoCl}_{2}$ introduction, as well as the analogous reaction of the EEl in tissues of heart, liver and kidneys may be due to the rapid penetration of heavy metals ions in tissues and its cytotoxic effects, the inclusion of these proteases in the destructive processes and by absence of their synthesis and/or release. The decreasing the cathepsin $\mathrm{G}$ activity in the lungs when $\mathrm{CoCl}_{2}$ was injected, as the EEl activation in the kidneys, may be associated with hypoxia-dependent effects of the toxicant. Decreasing of the thiol EEl activity in most of the samples at the $\mathrm{HgCl}_{2}$ introduction is associated with the loss of the proteinbound thiols and in the heart can cause to increased content of elastin and leads to the development of myocardial hypertrophy.

The study of these enzymes in people with metabolic disorders and hypertension is promising.

\section{ACKNOWLEDGEMENTS}

The authors are grateful the professor Kaliman P. A. from the Department of Biochemistry, V. N. Karazin Kharkov National University for his assistance in carrying out research.

\section{REFERENCES}

[1] Lang, I.A., Scarlett, A., Guralnik, J.M., Depledge, M.H., Melzer, D. and Galloway, T.S. (2009) Age-related impairments of mobility associated with cobalt and other heavy metals: data from NHANES 1999-2004. Journal of Toxicology and Environmental Health, 72, 402-409. doi:10.1080/15287390802647336

[2] Mats, J.M., Segura, J.A., Alonso, F.J. and Mrquez, J. (2010) Roles of dioxins and heavy metals in cancer and neurological diseases using ROS-mediated mechanisms. Free Radical Biology \& Medicine, 49, 1328-1341.

[3] Tkaczyk, C., Petit, A., Antoniou, J., Zukor, D.J., Tabrizian, M. and Huk, O.L. (2010). Significance of elevated blood metal ion levels in patients with metal-on-metal prostheses: An evaluation of oxidative stress markers. Open Orthopaedic Journal, 4, 221-227.

[4] Kaliman, P.A. and Okhrimenko, C.M. (2005) Cycle of the glucose-fatty acid in the oxidative stress in rats induced by cobalt chloride. Ukrainian Biochemical Journal, 77, 154-158.

[5] Tedtoeva, A.I., Dzugkoeva, P.S., Mozhayeva, I.W. and Dzugkoev, S.G. (2010) Lipid peroxidation, the activity of $\mathrm{Na}, \mathrm{K}-\mathrm{ATF}$ ase and antioxidant enzymes in rats with nephropathy induced by cobalt chloride. Biomedical Chemistry, 56, 540-544.

[6] Christova, T.Y., Duribanova, D.B. and Setchenska, M.S. (2002) Enhanced heme oxygenase activity increases the antioxidant defense capacity of guinea pig liver upon acute cobalt chloride loading: Comparison with rat liver. Comparative Biochemistry and Physiology, 131, 177184.

[7] Kamiya, T., Hara, H., Inagaki, N. and Adachi, T. (2010) The effect of hypoxia mimetic cobalt chloride on the expression of EC-SOD in 3T3-L1 adipocytes. Redox Report, 15, 131-137. doi:10.1179/174329210X12650506623483

[8] Padilla, M.A., Elobeid, M., Ruden, D.M. and Allison, D.B. (2010) An examination of the association of selected toxic metals with total and central obesity indices: NHANES 99-02. International Journal of Environmental Research and Public Health, 9, 3332-3347. doi:10.3390/ijerph7093332

[9] Azevedo, B.F., Futuro, Neto Hde, A., Stefanon, I. and Vassallo, D.V. (2011) Acute cardiorespiratory effects of intracisternal injections of mercuric chloride. Neurotoxicology, 32, 350-354. doi:10.1016/j.neuro.2011.02.006

[10] Furieri, L.B., Galán, M., Avendaño, M.S., GarcíaRedondo, A.B., Aguado, A., Martínez, S., Cachofeiro, V., Bartolomé, M.V., Alonso, M.J., Vassallo, D.V. and Salaices, M. (2011) Endothelial dysfunction of rat coronary arteries after exposure to low concentrations of mercury is dependent on reactive oxygen species. British Journal of Pharmacology, 162, 1819-1831. doi:10.1111/j.1476-5381.2011.01203.x

[11] Mahmoud, Z., Ladislas, R., Dominique, C., Pierre-Jean, T., Latifa, B. and Pierre, D. (2002) Serum elastase activity, serum elastase inhibitors, and occurrence of carotid atherosclerotic plaques. Circulation, 105, 2638-2645. doi:10.1161/01.CIR.0000017329.51160.EF

[12] Korkmaz, B., Horwitz, M.S., Jenne, D.E. and Gauthier, F. (2010) Neutrophil elastase, proteinase 3, and cathepsin G as therapeutic targets in human diseases. Pharmacological Reviews, 62, 726-759. doi:10.1124/pr.110.002733

[13] Tsuchiya, Y., Okada, G., Kobayashi, S., Chikuma, T. and Hojo, H. (2011) 4-Hydroxy-2-nonenal-modified glyceroldehyde-3-phosphate ehydrogenase is degraded by cathepsin G in rat neutrophils. Oxidative Medicine and Cellular Longevity, 2011, 213686.

[14] Brecher, A.S. and Dubord, R. (2008) Effect of acetaldehyde upon cathepsin G and chymase. NRAS implications. Digestive Diseases and Sciences, 53, 1311-1315. doi:10.1007/s10620-007-0013-0

[15] Jahanyar, J., Youker, K.A., Loebe, M., Assad-Kottner, C., 
Koerner, M.M., Torre-Amione, G. and Noon, G.P. (2007) Mast cell-derived cathepsin G: A possible role in the adverse remodeling of the failing human heart. Journal of Surgical Research, 140, 199-203. doi:10.1016/i.jss.2007.02.040

[16] Heinz, A., Jung, M.C., Jahreis, G., Rusciani, A., Duca, L., Debelle, L., Weiss, A.S., Neubert, R.H. and Schmelzer, C.E. (2012) The action of neutrophil serine proteases on elastin and its precursor. Biochimie, 94, 192-202. doi:10.1016/j.biochi.2011.10.006

[17] Kaliman, P.A. and Belovetskaya, I. (1986) Effect of cobalt chloride on the activity of key enzymes of heme metabolism in rat liver. Biochemistry, 51, 1302-1307.

[18] Maines, M.P., Kappas, A. (1977) Metals as regulators of heme metabolism. Science, 198, 1225-1221. doi:10.1126/science.337492

[19] Samokhina, L.M., Kravchenko, N.O. and Maksimova, N.A. (2002) Test-systems for determination of activity or concentration of cathepsin $\mathrm{G}$ in biological fluids. Ukraine Patent No. 44066A.

[20] Samokhina, L.M. and Maximova, N.A. (2004) Testsystems for determination of endothelial elastase activity in biological fluids. Ukraine Patent No. 45068.

[21] Yezhov, G.P., Babaev, A.A. and Novikov, V.V. (2007) Bioinformatic aspects of proteomics and protein degradation. Educational and methodological materials for the training program "Information storage and processing in biological systems". Nizhny Novgorod, 86.

[22] Klimova, O.A. (2009) The composition of individual proteolytic enzymes. Russia Patent No. 2365623.

[23] Dosenko, V.E. (1998) Determination of different forms of elastase in the aorta in experimental arteriosclerosis. Lab Diagnosis, 1, 24-27.

[24] Bradford, M.M. (1976) A rapid and sensitive method for the quantitation of microgram quantities of protein utilizing the principle of protein-dye binding. Analytical Biochemistry, 72, 248-254. doi:10.1016/0003-2697(76)90527-3

[25] Chaumont, A., Nickmilder, M., Dumont, X., Lundh, T., Skerfving, S. and Bernard, A. (2012) Associations between proteins and heavy metals in urine at low environmental exposures: Evidence of reverse causality. Toxicology Letters, 210, 345-52. doi:10.1016/j.toxlet.2012.02.005

[26] Pluteanu, F. and Cribbs, L.L. (2009) T-type calcium channels are regulated by hypoxia/reoxygenation in ventricular myocytes. American Journal of Physiology: Heart and Circulatory, 297, H1304-H1313. doi:10.1152/ajpheart.00528.2009

[27] Wei, S.S., Liao, X.X., Yang, C.T., Lin, J.Y., Yang, Z.L., Lan, A.P., Huang, X., Wang, L.C., Chen, P.X. and Feng, J.Q. (2009) Reactive oxygen species scavenger protects cardiac cells against injuries induced by chemical hypoxia. Nan Fang Yi Ke Da Xue Xue Bao, 29, 1977-1981.

[28] Qiao, H., Li, L., Qu, Z.C. and May, J.M. (2009) Cobaltinduced oxidant stress in cultured endothelial cells: Prevention by ascorbate in relation to HIF-1alpha. Biofactors, 35, 306-313. doi:10.1002/biof.43
[29] Yablonskaya, S.V., Filinska, O.M., Ostrovskaya, G.V. and Rybalchenko, V.K. (2009) Evaluation of hepatotoxicity of new derivative maleimides with cytostatic activity and its effect on lipid peroxidation and antioxidant system in liver. Ukrainian Biochemical Journal, 81, 83-92.

[30] Samokhina, L.M. and Samokhin, A.A. (2001) Chymase, elastase and tonin in rats under oxidative stress caused by the introduction of cobalt chloride. Ukrainian Biochemical Journal, 73, 47-51.

[31] Gemma, C., Vila, J., Bachstetter, A. and Bickford, P.C. (2007) Oxidative stress and the aging brain: From theory to prevention. In: Riddle, D.R., Ed., Brain Aging: Models, Methods, and Mechanisms, CRC Press, Boca Raton, 353374.

[32] Diaz, G.J., Julian, R.J. and Squires, E.J. (1994) Cobalt-induced polycythaemia causing right ventricular hypertrophy and ascites in meat-type chickens. Avian $\mathrm{Pa}$ thology, 23, 91-104. doi:10.1080/03079459408418977

[33] Matsuura, H., Ichiki, T., Ikeda, J., Takeda, K., Miyazaki, R., Hashimoto, T., Narabayashi, E., Kitamoto, S., Tokunou, T. and Sunagawa, K. (2011) Inhibition of prolyl hydroxylase domain-containing protein downregulates vascular angiotensin II type 1 receptor. Hypertension, 58, 386-393. doi:10.1161/HYPERTENSIONAHA.110.167106

[34] Legedz, L., Randon, J., Sessa, C., Baguet, J.P., Feugier, P., Cerutti, C., McGregor, J. and Bricca, G. (2004) Cathepsin $G$ is associated with atheroma formation in human carotid artery. Journal of Hypertension, 22, 157-166. doi:10.1097/00004872-200401000-00025

[35] Peters, K., Unger, R.E., Gatti, A.M., Sabbioni, E., Tsaryk, R. and Kirkpatrick, C.J. (2007) Metallic nanoparticles exhibit paradoxical effects on oxidative stress and pro-inflammatory response in endothelial cells in vitro. International Journal of Immunopathology and Pharmacology, 20, 685-695.

[36] Guo, Y., Yang, M.C., Weissler, J.C. and Yang, Y.S. (2007) PLAGL2 translocation and SP-C promoter activeity-A cellular response of lung cells to hypoxia. Biochemical and Biophysical Research Communications, 360, 659-665. doi:10.1016/i.bbrc.2007.06.106

[37] Tsoporis, J., Keeley, F.W., Lee, R.M. and Leenen, F.H (1998) Arterial vasodilation and vascular connective tissue changes in spontaneously hypertensive rats. Journal of Cardiovascular Pharmacology, 31, 960-962. doi:10.1097/00005344-199806000-00022

[38] Hoffman, D.J., Eagles-Smith, C.A., Ackerman, J.T., Adelsbach, T.L. and Stebbins, K.R. (2011) Oxidative stress response of Forster's terns (Sterna forsteri) and Caspian terns (Hydroprogne caspia) to mercury and selenium bioaccumulation in liver, kidney, and brain. Environmental Toxicology \& Chemistry, 30, 920-929. doi:10.1016/j.bbamcr.2012.01.005

[39] Gjnther, V., Lindert, U. and Schaffner, W. (2012) The taste of heavy metals: Gene regulation by MTF-1. Biochimica et Biophysica Acta, 1823, 1416-1425.

[40] Jan, A.T., Ali, A. and Haq, Q. (2011) Glutathione as an antioxidant in inorganic mercury induced nephrotoxicity. Journal of Postgraduate Medicine, 57, 72-77. 
doi:10.4103/0022-3859.74298

[41] Kaliman, P.A., Samokhin, A.A. and Samokhina, L.M. (2000) The proteinase-proteinase inhibitor system in rats with oxidative stress caused by the introduction of cobalt chloride. Ukrainian Biochemical Journal, 72, 89-92.
[42] Kaliman, P.A., Samokhin, A.A. and Samokhina, L.M. (2000) The proteinase-proteinase inhibitor system in rats by administration of mercury chloride. Animal Biology, 2, 152-156. 